\title{
IDENTIFIKASI JENIS LIANA DAN TUMBUHAN PENOPANGNYA DI BLOK PERLINDUNGAN TAMAN HUTAN RAYA WAN ABDUL RACHMAN
}

\section{(IDENTIFICATION OF LIANA AND ITS CANTILEVER PLANT SPECIES AT PROTECTION BLOCK OF WAN ABDUL RACHMAN GREAT FOREST PARK)}

\author{
Tiopan Tua Halomoan Simamora ${ }^{1)}$, Indriyanto ${ }^{2)}$, dan Afif Bintoro ${ }^{2)}$ \\ ${ }^{1)}$ Mahasiswa Jurusan Kehutanan Fakultas Pertanian Universitas Lampung, \\ ${ }^{2)}$ Staf Pengajar Jurusan Kehutanan Fakultas Pertanian Universitas Lampung, \\ Jurusan Kehutanan Fakultas Pertanian Universitas Lampung \\ J1. Soemantri Brojonegoro No. 1 Bandar Lampung, 35145 \\ E-mail : tiosimra@ymail.com
}

\begin{abstract}
ABSTRAK
Liana adalah salah satu jenis tumbuhan yang menjadi penciri khas dari ekosistem hutan hujan tropis dan keberadaannya menambah keanekaragaman jenis tumbuhan pada ekosistem hutan tersebut. Tujuan penelitian ini adalah mengidentifikasi jenis liana, dan tumbuhan penopangnya serta mengetahui jumlah jenis liana yang berasosiasi dengan tumbuhan penopang di Blok Perlindungan Taman Hutan Raya Wan Abdul Rachman khususnya yang masuk dalam Sub DAS Way Balau. Penelitian dilaksanakan pada bulan September sampai Oktober 2013. Metode sampling yang digunakan adalah garis berpetak. Ukuran setiap petak contoh $20 \mathrm{~m} \mathrm{x}$ $20 \mathrm{~m}$ dengan sub plot $10 \mathrm{~m} \times 10 \mathrm{~m}, 5 \mathrm{~m} \times 5 \mathrm{~m}, 2 \mathrm{~m} \times 2 \mathrm{~m}$. Liana dan tumbuhan penopang diinventarisir dengan inten-sitas sampling 0,2\% dari 796,50. Variabel yang diamati meliputi jenis dan jumlah individu liana, serta jenis dan jumlah individu tumbuhan penopang. Hasil penelitian yang telah ter-identifikasi yaitu 8 jenis liana dan 35 jenis tumbuhan penopang. Kerapatan liana sebesar 1.599 individu/ha dan kerapatan tumbuhan penopang sebesar 1.594 individu/ha, serta memiliki sebaran yang cukup baik karena tidak ada jenis yang mendominasi. Tumbuhan penopang yang paling disukai jenis liana adalah dadap (Erythrina lithosperma) dan liana paling banyak ditemukan yaitu rayutan (Paederia tomentosa).
\end{abstract}

Kata kunci: Blok Perlindungan Taman Hutan Raya Wan Abdul Rachman liana, tumbuhan penopang liana

\section{ABSTRACT}

Liana is one type of plant that becomes typical characteristic of a tropical rain forest ecosystem and its presence adds to the diversity of plant species in the forest ecosystem. The purposes of the study were to identify the species of liana, species of cantilever plant, and to know the number of liana species associated with the species of cantilever plant in the protection block of Wan Abdul Rachman Great Forest Park, especially in the area of Way Balau Sub watershed.

The research was conducted on September to Oktober 2013. The sampling method was used line terraced layer. The size of each sample plot was $20 \mathrm{~m} \times 20 \mathrm{~m}$ with sub plots $10 \mathrm{~m} \times 10$ $m, 5 m \times 5 m, 2 m \times 2 m$. Liana and cantilever plants species were inventoried by $0.2 \%$ sampling intensity from $796.50 \mathrm{ha}$. Observed variables were the species and the number of lianas, spesies of cantilever plant and its number. The result of research were identified 8 species of liana and 35 spesies of cantilever plants. Liana density was 1.599 individual/ha and cantilever plant density was 1.594 individual/ha, and it had a good enough distribution 
because there was no dominant species. The plant that most liked by liana is dadap (Erythrina lithosperma) and liana that mostly found is rayutan (Paederia tomentosa).

Keyword: cantilever plant, liana, Protection Block of Wan Abdul Rachman GreatForest Park

\section{PENDAHULUAN}

\section{Latar Belakang}

Liana atau tumbuhan pemanjat adalah salah satu jenis tumbuhan yang menjadi penciri khas dari ekosistem hutan hujan tropis dan keberadaannya menambah keanekaragaman jenis tumbuhan pada ekosistem hutan tersebut. Tumbuhan liana memanjat dan menopang pada tumbuhan lain hingga mencapai tajuk pohon dengan ketinggian tertentu. Contoh liana adalah sirih, rotan, anggur, labu, dan lain-lain.

Penelitian terhadap tumbuhan liana belum begitu banyak dilakukan, tetapi dari hasilhasil kajian yang telah dilakukan banyak peranan liana bagi ekosistem hutan dan perananya bagi masyarakat. Liana mempunyai peranan positif dan negatif untuk hutan dan lingkungannya. Peranan positif antara lain mencegah tumbangnya pohon akibat angin karena pertumbuhannya yang menjalar di antara pohon-pohon penopangnya dalam hutan, sebagai sumber pakan, dan sebagai alat pendukung bagi hewan yang melintas di pepohonan (Setia, 2009). Adapun peran negatif dari liana adalah dapat menyebabkan kerusakan pada tempat tertentu pada tumbuhan penopang yang dipanjatnya seperti luka pada batang pohon (Asrianny dkk., 2008).

Secara ekonomi, liana dapat bermanfaat sebagai obat-obatan contohnya daun sirih yang biasa digunakan oleh masyarakat sekitar hutan untuk menyembuhkan penyakit luka memar, keputihan, mencegah mimisan dan lain-lain. Selain itu liana seperti rotan dapat dijadikan sebagai barang kerajinan yang bernilai ekonomi misalnya dapat dibuat menjadi tas, bakul, keranjang, kursi, meja, bola takraw, dan tali pengikat.

Masyarakat dan pengelola Tahura Wan Abdul Rachman belum menggali potensi dan manfaat dari liana yang terdapat di Kawasan Tahura. Hal ini perlu diketahui karena masih belum ada informasi atau data yang lengkap mengenai identifikasi, potensi liana, dan keberadaan jenis-jenis liana di hutan tersebut yang dapat dimanfaatkan untuk berbagai kebutuhan hidup manusia. Oleh karena itu, penelitian ini dilaksanakan untuk melengkapi data serta informasi keberadaan jenis tumbuhan liana.

\section{METODE PENELITIAN}

\section{Tempat dan Waktu Penelitian}

Penelitian ini telah dilaksanakan di Blok Perlindungan Tahura Wan Abdul Rachman pada September 2013 sampai dengan Oktober 2013.

\section{Objek dan Alat Penelitian}

Objek penelitian berupa liana dan jenis tumbuhan penopang yang berasosiasi di Blok Perlindungan Tahura Wan Abdul Rachman. Alat penelitian yang digunakan adalah pita meter, tali rafia, kamera Cannon D3000, GPS, kunci determinasi, Software Microsof Excel.

\section{Metode Pengumpulan Data}

Data primer dihimpun dengan menggunakan metode garis berpetak yaitu dengan cara melompati satu atau lebih petak-petak pada jarak tertentu dengan jarak yang sama (Indriyanto, 2008). Petak pengamatan berukuran $20 \mathrm{~m}$ x $20 \mathrm{~m}$ dengan sub plot $10 \mathrm{~m}$ x $10 \mathrm{~m}$, 
$5 \mathrm{~m} \times 5 \mathrm{~m}, 2 \mathrm{~m} \times 2 \mathrm{~m}$ dan intensitas sampling yang digunakan sebesar 0,2\%. Dari luas total 796,50 ha akan diambil luas sampel 1,593 ha yang kemudian dibagi menjadi 40 petak contoh. Tata letak petak contoh disusun secara sistematis dengan jarak antar garis rintis $100 \mathrm{~m}$ dan jarak antarpetak contoh di dalam garis rintis adalah $100 \mathrm{~m}$. Jarak antar garis rintis dan jarak antarpetak ditentukan berdasarkan jarak pada peta kontur.

\section{Prosedur Penelitian}

Adapun langkah kerja yang dilakukan dalam penelitian ini yaitu :

1. Pembuatan plot berukuran $20 \mathrm{~m}$ x $20 \mathrm{~m}$ dengan sub plot $10 \mathrm{~m} \times 10 \mathrm{~m}, 5 \mathrm{~m} \times 5 \mathrm{~m}, 2 \mathrm{~m} \times 2$ m sebanyak 40 petak contoh.

2. Pengamatan terhadap jenis liana dan tumbuhan penopangnya yang terdapat dalam petak pengamatan.

3. Pengambilan jenis liana dan dilakukan identifikasi jenis liana dengan mengetahui bentuk morfologi liana (akar, batang, warna, buah, bunga, daun) dengan cara mencocokkan karakteristik morfus organ dengan literatur yang terdapat dalam monografi tumbuhan dan kunci determinasi serta diidentifikasi jenis tumbuhan penopang yang berasosiasi dengan jenis liana. Apabila ada jenis-jenis liana dan tumbuhan penopang tidak dapat diidentifikasi secara langsung di lapangan, maka dibuat spesimen untuk diidentifkasi lebih lanjut dengan herbarium (Kartawinata, 1997).

\section{Analisis Data}

Setelah data terkumpul, maka dilakukan analisis data sebagai berikut.

1. Kerapatan (Densitas)

Kerapatan $(\mathrm{K})$ jumlah individu per unit luas atau per satuan ruang (Gopal dan Bhardwaj, 1979 yang dikutip oleh Indriyanto, 2008).

2. Frekuensi (F)

$$
\mathrm{K}=\frac{\text { jumlah individu }}{\text { luas seluruh petak contoh }}
$$

Frekuensi menunjukkan jumlah penyebaran tempat ditemukannya suatu spesies dari semua petak contoh. Perhitungan frekuensi setiap jenis tumbuhan dapat diketahui dengan menggunakan rumus berikut (Gopal dan Bhardwaj, 1979 yang dikutip oleh Indriyanto, 2008).

$$
\mathrm{F}=\frac{\text { jumlah petak contoh ditemukannya suatu spesies }}{\text { jumlah seluruh petak contoh }}
$$

\section{HASIL DAN PEMBAHASAN}

\section{Jenis Liana dan Penopangnya di Blok Perlindungan Taman Hutan Raya Wan Abdul Rachman.}

Hasil penelitian di blok Perlindungan Taman Hutan Raya Wan Abdul Rachman didapatkan 8 jenis liana yang tersebar pada 40 petak contoh. Jenis-jenis liana dan tumbuhan penopang tersebut dapat disajikan dalam Tabel 1.

Berdasarkan Tabel 1 diketahui bahwa jenis liana rayutan (Paederia tomentosa) memiliki persentase $41,6 \%$ dari seluruh total jumlah jenis tumbuhan liana. Rayutan merupakan jenis liana yang paling banyak ditemukan di blok Perlindungan dalam Kawasan Taman Hutan Raya Wan Abdul Rachman. Hal ini diduga karena jenis liana rayutan merupakan jenis tumbuhan yang mudah penyebarannya, menyukai tempat lembab, dan mudah beradaptasi dengan tumbuhan lain. 
Tabel 1. Jenis liana yang ditemukan pada setiap fase pertumbuhan tumbuhan penopang di Blok Perlindungan Taman Hutan Raya Wan Abdul Rachman.

\begin{tabular}{|c|c|c|c|c|c|c|}
\hline \multirow[t]{2}{*}{ No. } & \multicolumn{2}{|c|}{ Jenis Liana } & \multicolumn{4}{|c|}{$\begin{array}{l}\text { Jumlah liana yang ditemukan } \\
\text { pada setiap fase pertumbuhan } \\
\text { tumbuhan penopang (individu/ha) }\end{array}$} \\
\hline & Nama Lokal & Nama Ilmiah & Pohon & Tiang & Pancang & Sema \\
\hline 1 & Brotowali & Tinospora cripa & 3 & 1 & 2 & 0 \\
\hline 2 & Lada & Piper nigrum & 5 & 3 & 3 & 0 \\
\hline 3 & Markisa & Passiflora edulis & 7 & 2 & 4 & 0 \\
\hline 4 & Rayutan & Paederia tomentosa & 36 & 42 & 31 & 24 \\
\hline 5 & Rotan cacing & Calamus heteroideus & 17 & 17 & 11 & 0 \\
\hline 6 & Sirih hutan & Piper caducibracteum & 8 & 6 & 7 & 0 \\
\hline 7 & Suruhan & Peperomia pellucida & 26 & 18 & 19 & 9 \\
\hline 8 & Vanili & Vanilla planifolia & 14 & 3 & 1 & 0 \\
\hline & Jumlah & & 116 & 92 & 78 & 33 \\
\hline
\end{tabular}

Tumbuhan yang paling banyak ditopangi liana berada pada fase pohon dan paling sedikit pada fase semai. Hal ini diduga karena pohon memberikan naungan dan cahaya yang lebih banyak dibandingkan dengan fase pertumbuhan lain yang ruang bawahnya cenderung tertutup. Liana cenderung memanjat, merambat, dan melilit pada batang, cabang, dan tajuk pohon untuk mendapatkan sinar matahari. Menurut Indriyanto (2008), liana merupakan tumbuhan yang akarnya melekat pada tanah, tetapi batang dan daunnya menjulang pada tumbuhan lain untuk memperoleh sumber cahaya matahari, sebagaimana hasil yang telah didapatkan bahwa batang liana merambat dan melilit pada tumbuhan lain untuk dapat tumbuh dan mendapatkan sinar matahari. Beberapa jenis liana budidaya seperti lada, brotowali, dan vanili ditemukan di Tahura Wan Abdul Rachman khususnya di blok Perlindungan. Hal ini diduga berhubungan dengan sejarah penggunaan lahan dimana pada blok perlindungan pernah digarap oleh petani terkait statusnya pada masa lalu kawasan tersebut merupakan lahan hutan kemasyarakatan (HKM) yang statusnya sebagai hutan lindung. Sesuai dengan data Dinas Kehutanan Provinsi Lampung (2006) bahwa Tahura Wan Abdul Rachman pada awalnya merupakan kawasan hutan lindung register 19 Gunung Betung. Kemudian berdasarkan keputusan Menteri Kehutanan Nomor 408/Kpts-II/1993 tanggal 10 Agustus 1993 diubah fungsinya menjadi Taman Hutan Raya Wan Abdul Rachman dan ditetapkan sebagai blok perlindungan yaitu memberi perlindungan mutlak ekosistem hutan alam, flora, fauna, dan proses hidrologi serta berfungsi sebagai perlindungan tata air (hidrologi).

Tabel 2. Jenis liana dan tumbuhan penopang pada semua fase tumbuhan di Blok Perlindungan Taman Hutan Raya Wan Abdul Rachman.

\begin{tabular}{|c|c|c|c|}
\hline No & Jenis liana & & Tumbuhan penopangnya \\
\hline 1 & Brotowali (Tinospora cripa) & $\begin{array}{l}1 . \\
2 . \\
3 . \\
4 . \\
5 . \\
6 .\end{array}$ & $\begin{array}{l}\text { Gintung (Bischofia javanica) } \\
\text { Jaling (Pithecellobium bubalinum) } \\
\text { Jambu mawar (Syzygium jambos) } \\
\text { Kaliandra (Calliandra calothyrsus) } \\
\text { Ki tulang (Kurrimia paniculata) } \\
\text { Sawo kecik(Manilkara kauki) }\end{array}$ \\
\hline 2 & Lada (Piper nigrum) & $\begin{array}{l}1 . \\
2 . \\
3 . \\
4 . \\
5 . \\
6 . \\
7 .\end{array}$ & $\begin{array}{l}\text { Aren (Arenga pinnata) } \\
\text { Dadap (Erythrina lithosperma) } \\
\text { Kaliandra (Calliandra calothyrsus) } \\
\text { Kiara (Ficus septica) } \\
\text { Pancang kidang (Aglaia elaegnoideag) } \\
\text { Pasang (Quercus gemelliflora) } \\
\text { Sawo kecik(Manilkara kauki) }\end{array}$ \\
\hline
\end{tabular}


Lanjutan Tabel 2.

\begin{tabular}{|c|c|c|}
\hline No & Jenis liana & Tumbuhan penopangnya \\
\hline 3 & Markisa (Passiflora edulis) & $\begin{array}{ll}\text { 1. } & \text { Dadap (Erythrina lithosperma) } \\
\text { 2. } & \text { Dahu (Dracontomelon mangiferum) } \\
\text { 3. } & \text { Gempol (Nauclea orientalis) } \\
\text { 4. } & \text { Jambu mawar (Syzygium jambos) } \\
\text { 5. } & \text { Kaliandra (Calliandra calothyrsus) } \\
\text { 6. } & \text { Medang (Litsea firma) } \\
\text { 7. } & \text { Medang seluang (Litsea spathulata) } \\
\text { 8. } & \text { Pasang (Quercus gemelliflora) } \\
\text { 9. } & \text { Sonokeling (Dalbergia latifolia) }\end{array}$ \\
\hline 4 & $\begin{array}{l}\text { Rayutan (Paederia } \\
\text { tomentosa) }\end{array}$ & $\begin{array}{ll}\text { 1. } & \text { Bintaro (Cebera manghas) } \\
\text { 2. } & \text { Bisoro (Ficus hispida) } \\
\text { 3. } & \text { Dadap (Erythrina lithosperma) } \\
\text { 4. } & \text { Dahu (Dracontomelon mangiferum) } \\
\text { 5. } & \text { Gintung (Bischofia javanica) } \\
\text { 6. } & \text { Jaling (Pithecellobium bubalinum) } \\
\text { 7. } & \text { Jambu mawar (Syzygium jambos) } \\
\text { 8. } & \text { Jelutung (Dyera costulata) } \\
\text { 9. } & \text { Kaliandra (Calliandra calothyrsus) } \\
\text { 10. } & \text { Kayu manis (Acmena melanostica) } \\
\text { 11. Kemiri (Aleurites moluccana) } \\
\text { 12. Kenari (Canarium vulgare) } \\
\text { 13. Ki tulang (Kurrimia paniculata) } \\
\text { 14. Kiara (Ficus septica) } \\
\text { 15. Kisalam (Acmena melanostica) } \\
\text { 16. Mara (Macaranga tanarius) } \\
\text { 17. Medang (Litsea firma) } \\
\text { 18. Pasang (Quercus gemelliflora) } \\
\text { 19. Pinangsi (Villebrunea rubescens) } \\
\text { 20. Pulai (Alstonia scholaris) } \\
\text { 21. Sawo kecik (Manilkara kauki) } \\
\text { 22. Sonokeling (Dalbergia latifolia) } \\
\text { 23. Tongtolok (Pterocymbium javanicum }\end{array}$ \\
\hline 5 & $\begin{array}{l}\text { Rotan cacing (calamus } \\
\text { heteroideus) }\end{array}$ & $\begin{array}{ll}\text { 1. } & \text { Aren (Arenga pinnata) } \\
\text { 2. } & \text { Bayur (Pterospermum javanicum) } \\
\text { 3. } & \text { Bintaro (Cebera manghas) } \\
\text { 4. } & \text { Dadap (Erythrina lithosperma) } \\
\text { 5. } & \text { Gambir (Trigonopleura malayana) } \\
\text { 6. } & \text { Gempol (Nauclea orientalis) } \\
\text { 7. } & \text { Jaling (Pithecellobium bubalinum) } \\
\text { 8. } & \text { Jambu mawar (Syzygium jambos) } \\
\text { 9. } & \text { Kenari (Canarium vulgare) } \\
\text { 10. } & \text { Mara (Macaranga tanarius) } \\
\text { 11. Medang (Litsea firma) } \\
\text { 12. Medang gabon (Litsea roxburghii) } \\
\text { 13. Medang seluang (Litsea spathulata) } \\
\text { 14. Pancang kidang (Aglaia elaegnoidea) } \\
\text { 15. Pasang (Quercus gemelliflora) } \\
\text { 16. Sawo kecik(Manilkara kauki) } \\
\text { 17. } \text { Tongtolok (Pterocymbium javanicum) }\end{array}$ \\
\hline
\end{tabular}


Lanjutan Tabel 2.

\begin{tabular}{|c|c|c|}
\hline No & Jenis liana & Tumbuhan penopangnya \\
\hline 6 & $\begin{array}{l}\text { Sirih hutan (Piper } \\
\text { caducibracteum) }\end{array}$ & $\begin{array}{ll}\text { 1. } & \text { Bayur (Pterospermum javanicum) } \\
\text { 2. } & \text { Dadap (Erythrina lithosperma) } \\
\text { 3. } & \text { Gempol (Nauclea orientalis) } \\
\text { 4. } & \text { Gintung (Bischofia javanica) } \\
\text { 5. } & \text { Jaling (Pithecellobium bubalinum) } \\
\text { 6. } & \text { Medang hiris (Aleurietes moluccana) } \\
\text { 7. } & \text { Pinangsi (Villebrunea rubescens) } \\
\text { 8. } & \text { Popoan (Brunchania arborescens) } \\
\text { 9. } & \text { Sawo kecik(Manilkara kauki) } \\
\text { 10. } & \text { Tongtolok (Pterocymbium javanicum) } \\
\text { 11. } & \text { Trembesi (Samanea saman) }\end{array}$ \\
\hline 7 & $\begin{array}{l}\text { Suruhan (Peperomia } \\
\text { pellucida) }\end{array}$ & $\begin{array}{ll}\text { 1. } & \text { Dadap (Erythrina lithosperma) } \\
\text { 2. } & \text { Gambir (Trigonopluera malayana) } \\
\text { 3. } & \text { Kemiri (Aleurites moluccana) } \\
\text { 4. } & \text { Kenari (Canarium vulgare) } \\
\text { 5. } & \text { Kisalam (Acmena melanostica) } \\
\text { 6. } & \text { Medang gabon (Litsea roxburghii) } \\
\text { 7. } & \text { Medang hiris (Aleurietesmoluccana) } \\
\text { 8. } & \text { Pancang kidang (Aglaia elaegnoidea) } \\
\text { 9. } & \text { Pulai (Alstonia scholaris) } \\
\text { 10. } & \text { Sonokeling (Dalbergia latifolia) } \\
\text { 11. } & \text { Tongtolok (Pterocymbium javanicum) }\end{array}$ \\
\hline 8 & Vanili (Vanilla planifolia) & $\begin{array}{ll}\text { 1. } & \text { Amplas (Ficus ampelas) } \\
\text { 2. } & \text { Dadap (Erythrina lithosperma) } \\
\text { 3. } & \text { Durian (Durio zibhetinus) } \\
\text { 4. } & \text { Gambir (Trigonopleura malayana) } \\
\text { 5. } & \text { Jaling (Pithecellobium bubalinum) } \\
\text { 6. } & \text { Jambu mawar(Eugenia garcinifolia) } \\
\text { 7. } & \text { Kemiri (Aleurites moluccana) } \\
\text { 8. } & \text { Kenari (Canarium vulgare) } \\
\text { 9. } & \text { Ki tulang (Kurrimia paniculata) } \\
\text { 10. } & \text { Kondang (Ficus variegata) } \\
\text { 11. } & \text { Merawan (Hopea mengarawan) } \\
\text { 12. } & \text { Pancang kidang (Aglaia elaegnoidea) } \\
\text { 13. Pasang (Quercus gemelliflora) } \\
\text { 14. Popoan (Brunchania arborescens) } \\
\text { 15. }\end{array}$ \\
\hline
\end{tabular}

Berdasarkan Tabel 2 diketahui bahwa jenis liana rayutan memiliki 23 jenis tumbuhan penopang dan brotowali memiliki 6 jenis tumbuhan penopang. Hal ini diduga bahwa rayutan merupakan jenis liana yang memiliki adaptasi paling baik terhadap berbagai spesies tumbuhan penopang dan brotowali paling rendah adaptasinya. Rayutan berasosiasi dengan banyak jenis tumbuhan penopang. Hali ini disebabkan karena adanya sifat rayutan yang mudah beradaptasi dengan baik. Secara ekologis rayutan tergolong jenis liana yang kisaran tempat tumbunya luas (eury). Sebaliknya brotowali paling sedikit adaptasinya karena brotowali tempat tumbuhnya sempit (steno) dan merupakan salah satu tumbuhan budidaya yang mana tumbuhan ini perlu perawatan serta sinar matahari yang cukup banyak. Sesuai dengan pendapat Greyti (2012), bagi tumbuhan dengan kisaran toleransi yang luas (eury) terhadap faktor lingkungan dalam hutan yang relatif konstant bukan merupakan faktor pembatas, sehingga tumbuhan tersebut dapat hadir dalam jumlah banyak. Sebaliknya, bagi tumbuhan dengan toleransi yang sempit (steno) terhadap faktor lingkungan dalam hutan yang selalu berubah akan menjadi faktor pembatas sehingga akan hadir dalam jumlah sedikit. Selain itu, Pratiwi (2011) juga berpendapat bahwa brotowali tumbuh lebih baik pada kondisi tempat terbuka serta banyak sumber cahaya matahari. 
Tabel 3. Jenis tumbuhan penopang dan liana yang berasosiasi di Blok Perlindungan Taman Hutan Raya Wan Abdul Rachman.

\begin{tabular}{|c|c|c|}
\hline No & Jenis tumbuhan penopang & Jenis liana \\
\hline 1. & Amplas & 1. Vanili \\
\hline \multirow[t]{2}{*}{2.} & Aren & 1. Lada \\
\hline & & 2. Rotan cacing \\
\hline \multirow[t]{2}{*}{3.} & Bayur & 1. Rotan cacing \\
\hline & & 2. Sirih hutan \\
\hline \multirow[t]{2}{*}{4.} & Bintaro & 1. Rayutan \\
\hline & & 2. Rotan cacing \\
\hline 5. & Bisoro & 1. Rayutan \\
\hline \multirow[t]{7}{*}{6.} & Dadap & 1. Lada \\
\hline & & 2. Markisa \\
\hline & & 3. Rayutan \\
\hline & & 4. Rotan cacing \\
\hline & & 5. Sirih hutan \\
\hline & & 6. Suruhan \\
\hline & & 7. Vanili \\
\hline \multirow[t]{2}{*}{7.} & Dahu & 1. Markisaa \\
\hline & & 2. Rayutan \\
\hline 8. & Durian & 1. Vanili \\
\hline \multirow[t]{3}{*}{9.} & Gambir & 1. Rotan cacing \\
\hline & & 2. Suruhan \\
\hline & & 3. Vanili \\
\hline \multirow[t]{3}{*}{10.} & Gintung & 1. Brotowali \\
\hline & & 2. Rayutan \\
\hline & & 3. Sirih hutan \\
\hline \multirow{3}{*}{11.} & Gempol & 1. Markisa \\
\hline & & 2. Rotan cacing \\
\hline & & 3. Sirih hutan \\
\hline \multirow[t]{5}{*}{12.} & Jaling & 1. Brotowali \\
\hline & & 2. Rayutan \\
\hline & & 3. Rotan cacing \\
\hline & & 4. Sirih hutan \\
\hline & Jambu mawar & $\begin{array}{ll}\text { 5. } & \text { Vanili } \\
\text { 1. } & \text { Brotowali }\end{array}$ \\
\hline \multirow{4}{*}{13.} & & 2. Markisa \\
\hline & & 3. Rayutan \\
\hline & & 4. Rotan cacing \\
\hline & & 5. Vanili \\
\hline 14. & Jelutung & 1. Rayutan \\
\hline \multirow[t]{4}{*}{15.} & Kaliandra & 1. Brotowali \\
\hline & & 2. Lada \\
\hline & & 3. Markisa \\
\hline & & 4. Rayutan \\
\hline 16. & Kayu manis & 1. Rayutan \\
\hline \multirow[t]{4}{*}{17.} & Kenari & 1. Rayutan \\
\hline & & 2. Rotan cacning \\
\hline & & 3. Suruhan \\
\hline & & 4. Vanili \\
\hline \multirow[t]{3}{*}{18.} & Kemiri & 1. Rayutan \\
\hline & & 2. Suruhan \\
\hline & & 3. Vanili \\
\hline \multirow[t]{2}{*}{19.} & Kisalam & 1. Rayutan \\
\hline & & 2. Suruhan \\
\hline \multirow[t]{2}{*}{20.} & Kiara & 1. Lada \\
\hline & & 2. Rayutan \\
\hline
\end{tabular}


Lanjutan Tabel 3.

\begin{tabular}{|c|c|c|}
\hline No & Jenis tumbuhan penopang & Jenis liana \\
\hline 21. & Kondang & 1. Vanili \\
\hline \multirow[t]{2}{*}{22.} & Mara & 1. Rayutan \\
\hline & & 2. Rotan cacing \\
\hline \multirow{3}{*}{23.} & Medang & 1. Markisa \\
\hline & & 2. Rayutan \\
\hline & & 3. Rotan cacing \\
\hline \multirow[t]{2}{*}{24.} & Medang gabon & 1. Suruhan \\
\hline & & 2. Rotan cacing \\
\hline \multirow[t]{2}{*}{25.} & Medang hiris & 1. Sirih hutan \\
\hline & & 2. Suruhan \\
\hline \multirow{2}{*}{26.} & Medang seluang & 1. Markisa \\
\hline & & 2. Rotan cacing \\
\hline 27. & Merawan & 1. Vanili \\
\hline \multirow{5}{*}{28.} & Pasang & 1. Lada \\
\hline & & 2. Markisa \\
\hline & & 3. Rayutan \\
\hline & & 4. Rotan cacing \\
\hline & & 5. Vanili \\
\hline \multirow[t]{4}{*}{29.} & Pancang kidang & 1. Lada \\
\hline & & 2. Rotan cacing \\
\hline & & 3. Suruhan \\
\hline & & 4. Vanili \\
\hline \multirow[t]{4}{*}{30.} & Pinangsi & 1. Rayutan \\
\hline & & 2. Rotan cacing \\
\hline & & 3. Sirih hutan \\
\hline & & 4. Suruhan \\
\hline \multirow[t]{3}{*}{31.} & Pulai & 1. Rayutan \\
\hline & & 2. Suruhan \\
\hline & & 3. Vanili \\
\hline \multirow[t]{4}{*}{32} & Sawo kecik & 1. Brotowali \\
\hline & & 2. Rayutan \\
\hline & & 3. Rotan cacing \\
\hline & & 4. Sirih hutan \\
\hline \multirow[t]{3}{*}{33.} & Sonokoling & 1. Markisa \\
\hline & & 2. Rayutan \\
\hline & & 3. Suruhan \\
\hline 34. & Tongtolok & 1. Sirih hutan \\
\hline 35. & Trembesi & 1. Sirih hutan \\
\hline
\end{tabular}

Berdasarkan hasil Tabel 3 diketahui bahwa dadap (Erythrina lithosperma) lebih banyak disukai spesies liana sebagai tumbuhan penopangnya. Hal ini diduga karena dadap merupakan salah satu tumbuhan yang cukup baik sebagai naungan. Selain batang dadap yang tegak, agak kasar, keras, dan cabang yang simpodial, dadap juga lebih menyukai tempat yang lembab.

Menurut Heyne (1987), dadap (Erythrina lithosperma) tumbuh pada tempat yang lembab, pohonnya agak bengkok tetapi umumya berukuran lebih sedang dan salah satu pohon yang baik sekali untuk naungan. Disamping itu, tumbuhan ini memberikan guguran daun cukup baik dan merata yang tidak dimiliki oleh pohon-pohon lain. Guguran daun menyusun penutup tanah yang baik sehingga dapat mempertahankan atau mendapatkan kebaikan struktur yang diharapkan. 


\section{Kerapatan, Frekuensi Jenis Liana dan Tumbuhan Penopangnya.}

Kerapatan dan frekuensi dari jenis liana dan penopangnya yang ditemukan di lokasi penelitian disajikan dalam Tabel 4 dan Tabel 5.

Tabel 4. Jenis liana, kerapatan, dan frekuensinya di Blok Perlindungan Taman Hutan Raya Wan Abdul Rachman.

\begin{tabular}{lllrl}
\hline No & Nama Lokal & \multicolumn{1}{c}{ Nama Ilmiah } & $\begin{array}{r}\text { Kerapatan } \\
\text { (individu/ha) }\end{array}$ & Frekuensi \\
\hline 1 & Brotowali & Tinospora cripa & 24,38 & 0,38 \\
2 & Lada & Piper nigrum & 40,63 & 0,23 \\
3 & Markisa & Passiflora edulis & 49,38 & 8,64 \\
4 & Rayutan & Paederia tomentosa & 812,50 & 1,63 \\
5 & Rotan cacing & Calamus heteroideus & 163,13 & 0,83 \\
6 & Sirih hutan & Piper caducibracteum & 90,00 & 0,48 \\
7 & Suruhan & Peperomia pellucida & 391,88 & 1,00 \\
8 & Vanili & Vanilla planifolia & 26,25 & 5,04 \\
\hline & & Jumlah Total & $\mathbf{1 . 5 9 9}$ & $\mathbf{1 8 , 2 0}$ \\
\hline
\end{tabular}

Berdasarkan Tabel 4 diketahui bahwa kerapatan dan frekuensi masing-masing jenis liana di lokasi penelitian sangat berbeda jumlahnya. Rayutan tergolong sangat tinggi kerapatannya, suruhan tergolong tinggi, rotan cacing tergolong sedang sementara jenis yang lain tergolong rendah. Jenis yang kerapatannya paling rendah adalah brotowali dan vanili. Kedua jenis tersebut memiliki kerapatan paling rendah karena keduanya merupakan tanaman budidaya yang sangat membutuhkan perawatan dan sumber cahaya matahari yang cukup, sehingga mampu berkembang dengan baik pada vegetasi hutan dengan penutupan tajuk lebih dari $75 \%$.

Frekuensi yang tergolong tinggi adalah markisa dan vanilla, frekuensi tergolong sedang adalah rayutan dan suruhan. Disini terlihat walaupun kerapatan rayutan tergolong tinggi tetapi penyebarannya tidak tersebar merata. Hal ini diduga karena rayutan menyukai tempat tumbuh tertentu. Sebaliknya vanili dan markisa walaupun kerapatannya rendah tetapi jenis ini tersebar merata. Hal ini diduga karena pada masa lalu vanili dan markisa dibudidayakan secara luas.

Tabel 5. Jenis tumbuhan penopang, kerapatan, dan frekuensinya di Blok Perlindunga Taman Hutan Raya Wan Abdul Rachman.

\begin{tabular}{llrc}
\hline No & Tumbuhan Penopang & $\begin{array}{c}\text { Kerapatan } \\
\text { (individu/ha) }\end{array}$ & Frekuensi \\
\hline 1 & Amplas & 0,31 & 0,01 \\
2 & Aren & 0,31 & 0,01 \\
3 & Bayur & 0,63 & 0,50 \\
4 & Bintaro & 31,25 & 0,01 \\
5 & Bisoro & 33,13 & 0,06 \\
6 & Dadap & 4,22 & 0,33 \\
7 & Dahu & 0,47 & 0,02 \\
8 & Durian & 0,47 & 0,02 \\
9 & Gambir & 78,44 & 0,12 \\
10 & Gempol & 0,31 & 0,01 \\
11 & Gintung & 0,63 & 0,03 \\
12 & Jaling & 129,22 & 0,42 \\
\hline
\end{tabular}


Lanjutan Tabel 5.

\begin{tabular}{llrc}
\hline No & Tumbuhan Penopang & $\begin{array}{r}\text { Kerapatan } \\
\text { (individu/ha) }\end{array}$ & Frekuensi \\
\hline 13 & Jambu mawar & 156,88 & 0,13 \\
14 & Jelutung & 32,50 & 0,11 \\
15 & Kaliandra & 312,50 & 0,19 \\
16 & Kayu manis & 58,13 & 0,09 \\
17 & Kemiri & 0,47 & 0,02 \\
18 & Kenari & 1,56 & 0,04 \\
19 & Kiara & 0,47 & 0,02 \\
20 & Kisalam & 38,44 & 0,31 \\
21 & Kondang & 0,16 & 0,01 \\
22 & Mara & 125,00 & 0,08 \\
23 & Medang & 49,69 & 0,36 \\
24 & Medang gabon & 47,19 & 0,06 \\
25 & Medang hiris & 31,88 & 0,11 \\
26 & Medang seluang & 48,13 & 0,10 \\
27 & Merawan & 0,16 & 0,01 \\
28 & Pancang kidang & 4,22 & 0,08 \\
29 & Pasang & 172,81 & 0,24 \\
30 & Pinangsi & 96,25 & 0,30 \\
31 & Pulai & 0,63 & 0,02 \\
32 & Sawo kecik & 64,06 & 0,27 \\
33 & Sonokeling & 62,97 & 0,09 \\
34 & Tongtolok & 9,69 & 0,07 \\
35 & Trembesi & 0,16 & 0,01 \\
\hline & Jumlah & $\mathbf{1 . 5 9 4}$ & $\mathbf{4 , 2 4}$ \\
\hline & & &
\end{tabular}

Berdasarkan Tabel 5 diketahui bahwa spesies tumbuhan penopang yang memiliki kerapatan terbesar adalah kaliandra sebesar 312,50 individu/ha. Kaliandra merupakan tumbuhan paling banyak ditemukan di Tahura Wan Abdul Rachman, hal ini diduga pada tahun 1992 dilakukan reboisasi hutan banyak di tanam pohon kaliandra dan penanamanya pada musim penghujan serta mudah beradaptasi dengan kondisi Tahura yang lembab. Menurut Tangendjaja dkk., (1992), keunggulan kaliandra dibandingkan dengan tanaman leguminosa lainnya yaitu mudah beradaptasi, berkembang pada berbagai kondisi tanah dan lingkungannya, tumbuh cepat dan banyak menghasilkan daun, toleransi terhadap pemangkasan, resisten terhadap gulma, penyakit dan kekeringan, mampu menekan pertumbuhan gulma, tumbuh pada semua jenis tanah, serta digunakan sebagai penutup tanah karena memiliki guguran daun yang baik menyebabkan jenis pohon yang tumbuh dominan pada tempat tersebut berbeda pula.

\section{KESIMPULAN}

Berdasarkan hasil penelitian dan pembahasan dapat disimpulkan sebagai berikut.

1. Jenis-jenis liana yang terdapat di Blok Pelindungan dalam kawasan Tahura Wan Abdul Rachman yang teridentifikasi ada 8 jenis liana dengan 35 jenis tumbuhan penopang.

2. Kerapatan liana memiliki 1.599 individu/ha dan tumbuhan penopang memiliki 1.594 individu/ha memiliki sebaran yang cukup baik dan merata di setiap plot. 
3. Jenis liana paling banyak ditemukan yaitu rayutan (Paederia tomentosa) dan tumbuhan penopang yang paling disukai jenis liana adalah dadap (Erythrina lithosperma).

\section{DAFTAR PUSTAKA}

Asrianny, Marian, dan N. P. Oka. 2008. Keanekaragaman dan kelimpahan jenis liana (tumbuhan memanjat) pada hutan alam di hutan pendidikan Universitas Hasanuddin. Jurnal Perennial. Makasar. 5(1):23-30.

Dinas Kehutanan Provinsi Lampung. 2006. Master Plan Taman Hutan Raya Wan Abdul Rachman. Buku. Laras Sembada. Jakarta. 142 p.

Greyti. 2012. Konsep factor lingkungan. Jakarta. Diakses November 2012. http://griyti. Blogspot.com 2012/11/01.html

Heyne, K. 1987. Tumbuhan Berguna Indonesia II. Buku. Badan Penelitian dan Pengembangan Kehutanan. Departemen Kehutanan. Yayasan Sarana Wana Jaya. Jakarta. $642 \mathrm{p}$.

Indriyanto. 2008. Ekologi Hutan. Buku. Bumi Aksara. Jakarta. 210 p.

Kartawinata, K. 1997. Beberapa catatan tentang cara-cara herbarium. Jurnal Perennial. Universitas Mulawarman Samarinda. Samarinda. 4(7):51-28.

Pratiwi, R. 2011. Efek hepatoprotektor brotowali terhadap virus hepatitis B. Jurnal ilmiah biologi dan kesehatan. Surakarta.4(1):15-24.

Setia, T. M. 2009. Peran liana dalam kehidupan orang hutan. Jurnal Penelitian dan Pengembangan Hutan. Jakarta. 2(1): 55-61.

Tangendjaja, B. E. Wina, T. M. Ibrahim, dan B. Palmer. 1992. Kaliandra (Calliandra calothyrsus) dan Manfaatnya. Jurnal ACIAR. Balai Penelitian Ternak dan The Australian Centre For Institute Agricultural Research. Bogor. 9(2):13—42. 
Vol. 3 No. 2, Mei 2015 (31-42)

Halaman ini sengaja dikosongkan 